Лозинська О. І., аспірант Харківський національний економічний університет імені Семена Кузнеия м. Харків, Украӥна

DOI: https://doi.org/10.30525/978-9934-26-028-5-51

\title{
ВИЗНАЧЕННЯ ПІДХОДІВ ДО ФОРМУВАННЯ СИСТЕМИ ПОКАЗНИКІВ ОЦІНКИ РІВНЯ ДІДЖИТАЛІЗАЦІЇ ФІНАНСОВИХ УСТАНОВ НА РИНКУ ФІНАНСОВИХ ПОСЛУГ
}

\begin{abstract}
Використання фінансових технологій (FinTech) є ключовою ознакою діяльності сучасних фінансових компаній, які використовують фінансові інновації в поєднанні з можливостями IT i, тим самим, дозволяють реалізувати додаткові можливості розвитку ринку фінансових послуг. Застосування нових підходів на етапі взаємодії фінансових установ (банків та інших) 3 користувачами фінансових послуг (клієнтами банків) створює значний синергетичний ефект від поєднання таких можливостей, підвищує рівень комфорту споживачів фінансових послуг, продукує умови для забезпечення сприятливого інвестиційного клімату в країні, та в загальному сенсі сприяе формуванню цифрового простору і позитивного іміджу економіки країни.

Аналіз показників статистики в аспекті існуючих тенденцій цифровізації фінансового ринку України підтверджує достатньо
\end{abstract}


високий потенціал для забезпечення зростання фінтех-компаній та відповідних сервісів, що $є$ свідчення високого рівня його конкурентоспроможності. Сучасні методики інтегральної оцінки діджиталізації світової економіки у розрізі окремих галузей свідчать про масштабні зміни у відносинах між учасниками фінансових відносин (державні установи, фінтех-компанії, «класичні» учасники фінансового ринку, інвестори, суспільство) під впливом інтеграції як традиційних, так i інноваційних цифрових технологій.

Використання такого методичного інструментарію дозволяє порівнювати ефективність функціонування економік світу, створювати відповідні рейтинги та в подальшому проводити аналіз факторів, які дозволили окремим країнам досягти таких значущих результатів. Це вимагає необхідності проведення системних досліджень 3 метою систематизації і узагальнення досвіду використання відповідного інструментарію оцінювання ступеня діджиталізації як на рівні економік країн (макрорівень), так і відповідних сфер діяльності (галузей або секторів), а також для визначення і порівняння рівня цифровізації окремих банків (мікроекономічний аспект).

Завдяки достатньому проникненню інтернету, зокрема мобільному, в усі аспекти економічного життя ми можемо констатувати, що в Україні активно відбуваються процеси переходу до організації цифрового бізнесу на основі використання цифрових технологій для зміни бізнес-моделі. Наслідком такої трансформації виступають саме ті додаткові можливості, які дозволяють отримувати у найближчому майбутньому додатковий прибуток чи нову якість фінансового активу.

Запровадження зручних цифрових сервісів дозволяє надати людям змогу скористатися багатоаспектними зручностями сучасної фінансової системи, суттєво змінити формат існуючих видів діяльності. При цьому, дослідники Т. Окс і Ю.А. Ріман надають характеристику «процесам діджиталізації як інтеграцію цифрових технологій у повсякденне життя ляхом перенесення у цифровий формат усього, що можна діджиталізувати» [1]. 
Такий підхід дозволяє вбачати необмежений масштаб і потенціал використання цифрових технологій, де беззаперечними лідерами залишаться саме банки як провідні представники надавачівпосередників на ринку фінансових послуг.

На сучасному етапі дослідження проблематики більш-менш усталеним можна вважати підхід до вимірювання рівня діджиталізації певних секторів економіки, запропонований Глобальним інститутом McKinsey (McKinsey Global Institute) [2], відповідно до якого загальний індекс містить три субіндекси: 1) витрати на цифрові активи (витрати на апаратне забезпечення, витрати на програмне забезпечення та IT-послуги, витрати на телекомунікаційне обладнання); 2) витрати на цифрові активи в розрахунку на одного працівника (витрати на апаратне забезпечення в розрахунку на одного працівника, витрати на програмне забезпечення та IT-послуги в розрахунку на одного працівника, витрати на телекомунікаційне обладнання в розрахунку на одного працівника); 3) нарощування цифрового капіталу (загальний обсяг апаратного забезпечення в розрахунку на одного працівника, загальний обсяг програмного забезпечення в розрахунку на одного працівника).

На противагу такому підходу, Європейською Комісією було розроблено Індекс цифрової економіки та суспільства (Digital Economy and Society Index - DESI, 2014 p.), який відображає розвиток цифрової економіки $\mathrm{CC}$ та його країн-членів, i Міжнародний індекс цифрової економіки та суспільства (International Digital Economy and Society Index - I-DESI, 2016 p.), який вимірює показники цифрової економіки країн - членів СС порівняно із 17 іншими країнами світу (Австралія, Бразилія, Канада, Чилі, Китай, Ісландія, Ізраїль, Японія, Мексика, Нова Зеландія, Норвегія, Росія, Сербія, Південна Корея, Швейцарія, Туреччина і США) [3].

Відображення i розширення результатів Індексу цифрової економіки та суспільства (DESI) шляхом пошуку індикаторів, які відображають аналогічні трансформації в країнах, що не входять до $Є С$ здійснюється на основі розрахунку двох індексів, які 
в свою чергу визначаються п'ятьма індикаторами: 1) зв'язок (розширення широкосмугової інфраструктури та іiі якість); 2) людський капітал - цифрові навички (навички, необхідні для використання можливостей, які формуються в умовах розвитку цифрового суспільства); 3) використання громадянами Інтернету (різні види діяльності, що здійснюються громадянами в Інтернеті); 4) інтеграція бізнес-технологій (діджиталізація бізнесу і розвиток каналу онлайн-продажів); 5) цифрові державні послуги (діджиталізація державних послуг і формування електронного уряду).

Існують також й інші методики вимірювання рівня діджиталізації на рівні окремих галузей економіки (Міжнародного союзу електрозв'язку), що є свідченням про те, що універсальної методики, яка враховує сучасні умови їх функціонування.

Інша ситуація складається при вирішенні даної проблеми на мікрорівні. Існуючого усталеного і загальноприйнятного переліку показників для оцінки рівня діджиталізації окремих банків в сучасному вимірі часу для здійснення їх порівняння i рейтингування не існує. Труднощі 3 доступом до офіційної інформації щодо параметрів вимірювання окремих аспектів інноваційної діяльності мають місце і також не є систематизованими, обов'язковими. Такий стан речей призводить до неможливості формування «класичної» системи показників 3 метою оцінювання рівня діджиталізації окремого банку в аспекті порівняння його з іншим.

Вирішення даного завдання (формування системи показників), на наш погляд, можливе за рахунок відбору певних параметрівхарактеристик діяльності банків, які використовують інноваційні фінансові технології і можуть бути визначені усіма банками у якості загальноприйнятних при оцінюванні, що призводить або може призвести до якісних змін (результативності діяльності). Це в першу чергу може бути пов'язано і з розвитком клієнтської бази, кількістю персоналу, новими видами та кількістю фінансових послуг, фінансових сервісів, зростанням прибутку, i розширенням географії діяльності банку. 
В умовах активізації процесів трансформації своїх бізнесмоделей, вітчизняні банки через підвищення інтересу до фінансових технологій i співпрацю 3 фінтех-компаніями все більше залучаються у фінтех-екосистему. Найпоширенішою моделлю співпраці $є$ спільні проекти, ніж розвиток власних «центрів інновацій» (ПриватБанк). Реалізація таких проектів дозволяє банкам уникати зайвих інвестиційних витрат та мінімізувати ризики. Практично усі інші вітчизняні банки першої двадцятки (за опитуванням аналітиків) не зацікавлені у здійсненні операцій з інвестування в стартами як такі, що не відносяться до «класичних» (призводять до корегувань капіталу банків у відповідності з діючим законодавством) банківських операцій.

Результати дослідження даної проблеми дозволяють підтвердити доцільність при визначенні переліку показників (параметрів-характеристик) враховувати й наступні кількісні параметри такої співпраці (кількість транзакцій, кількість стартапівпроєктів; обсяги їх фінансування; кількість віддалено ідентифікованих клієнтів; зміна кількості платіжних сервісів; спрощення й прискорення платежів; застосування систем тучного інтелекту на етапі попередження шахрайських або ризикових операцій; підвищення рівня автоматизації бізнес-процесів та використання великих баз даних; зменшення ризику, фінансових i інших видів втрат від своєчасних заходів забезпечення кібербезпеки, надійність сервісів, їх токенізація та ін.).

Для обгрунтованості такого підходу доречно привести рейтинг ТОП-10 банків за результатами брендових запитів користувачів українською та англійською мовами за 9 місяців року, представлений за версією журналу Banker.Ua (жовтень, 2020), який дозволяє визначити популярність банку як бренду у мережі інтернет; рівень відвідуваності сайту (табл. 1) [4].

Загальний рейтинг дозволяє Banker.ua досліджувати рівень діджиталізації українських банків та складати рейтинг «ТОП-20 digital-банків України», який складається 3 п’яти розділів - крім того, кількість підписників у соцмережах та скачувань 
мобільного додатку, а також ефективність спілкування 3 клієнтами онлайн дозволяють доповнити загальне враження.

Таблиця 1

\section{Рейтинг ТОП-10 банків}

за результатами брендових запитів користувачів

\begin{tabular}{|c|c|c|c|c|}
\hline № & БАНК & $\begin{array}{c}\text { Укр/Рос } \\
\text { Середня кількість } \\
\text { запитів протягом } \\
\text { місяця }\end{array}$ & $\begin{array}{c}\text { Англ } \\
\text { Середня кількість } \\
\text { запитів протягом } \\
\text { місяця }\end{array}$ & $\begin{array}{c}\text { Усього } \\
\text { за 9 } \\
\text { місяців }\end{array}$ \\
\hline \multicolumn{5}{|c|}{ Державні банки } \\
\hline 1 & ПриватБанк & 673000 & 2400 & 6078600 \\
\hline 2 & Ощадбанк & 550000 & 9900 & 5039100 \\
\hline 3 & УКРГАЗБАНК & 90500 & 3600 & 846900 \\
\hline 4 & Укрексімбанк & 41900 & 2900 & 403200 \\
\hline \multicolumn{5}{|c|}{ Комериійні банки } \\
\hline 5 & Альфа-Банк & 301000 & 9900 & 2798100 \\
\hline 6 & ПУМБ & 246000 & 22200 & 2413800 \\
\hline 7 & УКРСИББАНК & 203900 & 27100 & 3079000 \\
\hline 8 & топовапк & 135000 & 60300 & 1759500 \\
\hline 9 & ОТП Банк & 90500 & 27300 & 1058400 \\
\hline 10 & $\begin{array}{c}\text { Райффайзен банк } \\
\text { Аваль }\end{array}$ & 90500 & 6600 & 873900 \\
\hline
\end{tabular}

Статистика станом на кінець 2020 року підтверджує, що:

- ПриватБанк - 25 млн клієнтів-фізичних осіб 1974 відділення - шерінг працює у всіх відділеннях України 28 клієнтів вже скористалися шерінгом;

- monobank - 2,8 млн клієнтів, на сьогодні 3796 заявок на реєстрацію через документи в Дії, 3 них активних клієнтів 491 (віртуальний рахунок або картка в точці видачі), менше 20 хвилин для відкриття рахунку, використовуючи е-документи в Діï;

- А-Банк - 3 млн клієнтів 455 точок входу: 230 відділень по всій країні, 225 точок РІП (в магазинах) запустили шерінг по всіх відділеннях банку, вже успішно відпрацьовано 28 запитів [5]. 
3 початку пандемії ми АТ «Кредобанк» значно прискорив роботу 3 діджиталізації банку та впровадили низку нових сервісів, серед яких - перший в Україні сервіс «Відеоконсультант онлайн». Даний сервіс доповнює достатньо великий перелік вже існуючих сервісів:

- сервіс онлайн-відкриття рахунків для фізичних осіб, який дозволяє відкривати рахунки та отримувати банківські карти без візиту до відділення;

- послуга дистанційного відкриття рахунків для юридичних осіб та фізичних осіб-підприємців;

- дистанційне замовлення довідки за чинним кредитом через заповнення заявки на сайті банку;

- послуга онлайн-подання звітності позичальниками юридичними особами;

- онлайн-банкінг для роздрібних клієнтів додатково до базових операцій дозволяє проводити онлайн-обмін валют у реальному часі за вигідними курсами, що особливо зручно для поповнення валютних карт; здійснення попередньо налаштованих авто платежів;

- подання заявки на кредит;

- керування всіма платіжними картами;

- здійснення онлайн-платіжу за послуги пункту подачі візових анкет;

- придбати полісу туристичного страхування або страхування авто без візиту у відділення (Довідка: АТ «КРЕДОБАНК»).

Окремої уваги заслуговують перспективні зміни від набуття нової якості застосування «класичних» банківських сервісів, які $\epsilon$ очікуваними, але вже від впровадження нової фінансової філософії їх реалізації. Так банківські картки суттєво вже змінили своє призначення, їх можна розглядати не як звичайний платіжний інструмент, а вважати ключем (доступність - 24/7/365, можливо 3 певними новими системами захисту інформації, доступу до послуг у сфері фінансового менеджменту, страхових послуг, податкових платежів) до багатьох інших сервісів в звичайному повсякденному житті (представницьких функцій, 
туристичні подорожі, транспорт, замовлення послуг, чатботкомерція, медичні послуги, система цифрової репутації та ін.). Для формування показників саме за такими окремими компонентами щодо оцінювання рівня діджиталізації саме банків можливе використання експертного методу (опитування).

Поява альтернативних платіжних методів (біометричних) ідентифікації, оплати за допомогою технологій FaceID та TochID започаткували нові можливості для наявних i потенційних споживачів (популяризація банкінгу через месенджери) фінансових послуг, у тому числі для переходу на безготівкові платежі розвиненої кешлес-економіки в форматі глобального цифрового простору, шерінгової економіки (Sharing Economy), або економіки спільного споживання (Collaborative Consumption) - нової культури і економічної моделі, коли за допомогою технологій і онлайн платформ люди мають можливість здійснювати обмін активами, які не використовують.

За переконанням Олени Коробкової, виконавчого директора НАБУ, розвиток інноваційних сервісів можливе тільки за двох умов: «Перша умова - відповідне, адаптоване до реалій і новацій, регуляторне поле. В цьому контексті моменти ідентифікації клієнтів і дотримання правил фінансового моніторингу під час впровадження нових технологій є одними 3 ключових. Друга умова - інвестиції». Так, протягом останніх трьох років український технологічний сектор демонструє зростання на середньому рівні $28 \%$ на рік [6].

Запропонований підхід до формування системи показників оцінки рівня діджиталізації фінансових установ заслуговує на увагу також і на етапі формування маркетингової стратегії банку в умовах поглиблення процесів цифровізації національної економіки як складової загальної стратегії забезпечення конкурентоспроможності банку на ринку фінансових послуг. Це дозволить забезпечити банкам реалізацію їх конкурентних переваг на основі дослідження й визначення впливу або взаємозв'язку між параметрами рівня діджиталізації і рівнем 
конкурентоспроможності на ринку фінансових послуг на етапі прийняття управлінських рішень.

\section{Література:}

1. Ochs T., Riemann U.A. IT Strategy Follows Digitalization. Encyclopedia of Information Science and Technology, Fourth Edition. Hershey, PA : IGI Global, 2018. DOI: 10.4018/978-1-5225-2255-3.ch075.

2. The Rise of Digital Challengers. Digital. McKinsey. URL: https://digitalchallengers.mckinsey.com.

3. International Digital Economy and Society Index 2018. SMART 2017/0052. Publications Offce of the European Union. Luxembourg, 2018. URL: https://ec.europa.eu/digital-single-market/en/news/international-digital-economy-andsociety-index-2018.

4. Печатное издание “Банкер”. URL: https://banker.ua/magazine.

5. Офіційний сайт НБУ. URL: https://bank.gov.ua/ua/news/all/nbu-ta-mintsifrispilno-pratsyuyut-nad-tsifrovizatsiyeyu-bankivskoyi-sistemi-ukrayini.

6. Коробкова О. Діджиталізація: як далі це явище змінюватиме життя українців? URL: https://nabu.ua/ru/olena-korobkova-15.html. 